African Crop Science Journal by African Crop Science Society is licensed under a Creative Commons Attribution 3.0 Uganda License. Based on a work at www.ajol.info/ and www.bioline.org.br/cs DOI: http://dx.doi.org/10.4314/acsj.v25i1.3

\title{
CASSAVA BROWN STREAK DISEASE EFFECTS ON LEAF METABOLITES AND PIGMENT ACCUMULATION
}

\author{
E. NUWAMANYA, Y. BAGUMA ${ }^{1}$, E. ATWIJUKIRE, S. ACHENG, P. ABIDRABO, C.A. OMONGO \\ and T. ALICAI \\ Root Crops Research Program, National Crops Resources Research Institute, P. O. Box 7084, \\ Kampala, Uganda \\ ${ }^{1}$ Directorate of Research Coordination, National Agricultural Research Organization, P. O. Box 295, \\ Entebbe, Uganda \\ Corresponding author: nuwamanyaephraim@gmail.com
}

(Received 20 May, 2016; accepted 8 February, 2017)

\begin{abstract}
Cassava Brown Streak Disease (CBSD) is a threat to productivity and product quality in East Africa. The objective of this study was to understand the effect of CBSD on the primary photosynthetic apparatus of cassava (Manihot esculenta Crantz). Three cassava varieties with varying levels of reaction to infection by CBSD were chosen and subjected to field disease pressure. Disease progression and the resulting effects on leaf morphology, metabolite and pigment accumulation were assessed over a period of five months, beginning from 3 months after planting. Slight increments in leaf dry matter were observed up to 4 MAP, and there after a drop was registered. A significant $(\mathrm{P}<0.05)$ reduction in photosynthetic pigments occured with a fall in the Chla:Chlb and Chla:Carotenoid ratio, indicative of specific reductions in chlorophyll $a(-80 \%)$ compared to Chlorophyll $b$ (-41 to $-62 \%)$ and Carotenoid (-11 to $-18 \%)$. Total reducing sugar and starch content also dropped significantly (-30 and $-60 \%$, respectively), much as NASE 14 maintained a relatively higher amount of carbohydrates. Leaf protein levels were significantly reduced at a rate of $0.07 \mathrm{ug} \mathrm{g}^{-1}$ leaf per month in diseased treatments. Significant reductions in primary metabolites show altered leaf photosynthetic and growth metabolism, resulting into a compromised plant system that cannot perform optimally.
\end{abstract}

Key Words: Carotenoid, leaf metabolites, photosynthesis, protein

\section{RÉSUMÉ}

La Maladie Striée Brune du Manioc (CBSD) constitue une menace pour la productivité et la qualité des produits du manioc en Afrique de l'Est. L'objectif de cette étude était de comprendre l'effet de CBSD sur l'appareil photosynthétique primaire du manioc (Manihot esculenta Crantz). Trois variétés de manioc possédant differents niveaux de résistance à CBSD ont été soumises à la pression dans les conditions de plein champs. La progression de la maladie et son effet sur la morphologie foliaire, les metabolites et accumulations de pigments ont été évalués sur une période de cinq mois, à compter du troisième mois après semis. Il a été observée une légère augmentation de matière sèche foliaire jusqu'à 4 MAP, suivie d'une chute. Une réduction significative $(\mathrm{P}<0,05)$ des pigments photosynthétiques a été observée avec une chute dans le Chla:Chlb et Chla:ratio de Carotenoide, indiquant des réductions spécifique sen chlorophylle $a(-80 \%)$ en comparaison avec la Chlorophylle $b(-41$ à $-62 \%)$ et les Carotenoides (-11 à -18\%). La réduction du sucre et d'amidona connu aussi une diminution significative (-30 et $-60 \%$, respectivement), de même NASE 14 a maintenuun equantité relativementé levée d'hydrates de carbone.

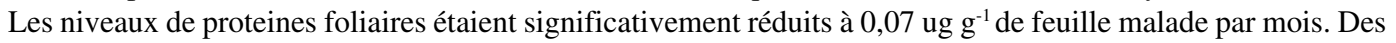


réductions significatives des metabolites primaires sont à l'origne de l'altération du métabolisme photosynthétique et de croissance, resultant à cycle végétatif compromis qui ne peut permettre un développement optimal de la plante.

Mots Clés: Carotenoides, metabolites foliaires, photosynthèse, proteine

\section{INTRODUCTION}

Cassava (Manihot esculenta Crantz) is a main food crop in Sub-Saharan Africa (SSA), Asia and Latin America, for more than 280 million inhabitants. Cassava brown streak disease (CBSD) is one of the most devastating diseases (Pennisi, 2010), difficult to identify and manage; hence resulting in almost $100 \%$ yield losses (Ogwok et al., 2012). The disease (CBSD) has a significant effect on leaf morphology, with observable browning of leaves (Mbanzibwa et al., 2009). The causal viruses (Cassava brown streak virus (CBSV), and Uganda cassava brown streak virus (UCBSV) produce a range of foliar symptoms that include brown streak patterns on the stem, reduction in leaf and plant sizes and early leaf senescence (Alicai et al, 2007).

The symptoms are associated with cellular modifications, depending on whether cassava is infected with a single or multiple viruses, resulting in synergistic interactions (Ogwok et al., 2012,). The symptoms also depend on the age of the plant and the weather; making it difficult to differentiate the resultant effects. The symptoms show a general yellowing, pointing to loss of green pigmentation in the leaves; and hence it is postulated that there is a general effect of the disease on photosynthesis (Alicai et al., 2007; Mbazibwa et al., 2009; Ogwok et al., 2012). Like other viral diseases, the loss in yield is evident, much as the loss in root dry matter content is not obvious (Nuwamanya et al., 2015).

The effects on the leaf and stem, which determine the level of photoassimilates that can be stored in the root, have a general effect on the yield of the plant. In particular, the deposition of lignified material in the root is a result of altered metabolism in the leaf (Nuwamanya et al., 2015), which affects the starch yield and the utilisation of cassava roots (Mbazibwa et al., 2011).

Viral establishment and infection have long been known to be facilitated by phloem loading and unloading mechanisms in the leaves (Haywood et al., 2002). However, the effects of the existence of viral particles in the phloem, on photo-assimilate production and transport has not been fully studied. Such effects, dependent on the virus-host interactions, differ in a number of plants and may determine the type of assimilate unloaded into the sink or even the form in which viral particles are translocated within the plant (Chen et al., 2000). Xylem transport of viruses and viral particles has also been suggested (Moreno et al., 2004) through the movement of viruses and the effects on plant metabolism may be specific to phloem tissues.

Systemic viral effects mainly start in the leaf, and hence, have a bearing not only on photo-assimilate production and transport (Shaltin and Wolf, 2000), but also on the structure of photosynthetic apparatus (Moreno et al., 2004). This leads to biochemical and physiological changes, which help in setting up viral symptomology and changes in both carbohydrate and nitrogen contents. Specifically and depending on the virus, changes in sugars and total carbohydrates occur as a result of decreased sugar synthesis or increased respiration, as the virus affects the plant (Shaltin and Wolf, 2000).

The objective of this study was, therefore, to determine specific effects of the virus on cassava leaf (source of photoassimilates) architecture. 


\section{MATERIALS AND METHODS}

Cassava varieties used. Three cassava varieties were selected on the basis of their reaction to infection by CBSD. These included the tolerant elite variety (NASE 14) that is being promoted for farmer adoption (Kawesi et al., 2014), the CBSD susceptible variety (TME 204) (Katono et al., 2015) and the farmer preferred but CBSD susceptible Alado as the local check. NASE 14 is so far a variety of choice for many farmers, since it combines a significant level of reaction to infection by CBSD and is comparatively high yielding (Katono et al., 2015). On the other hand, TME 204 , used to be a preferred elite variety but is susceptible to CBSD. In addition, these varieties form a significant percentage of cassava in popular cassava growing areas of the country, and are thus vital for food security.

Disease-free stem cuttings of these varieties were sourced from cassava seed farmers in Kiryadongo district, planted in a completely randomised block design field experiment, at the National Crops Resources Research Institute (NaCRRI) at Namulonge in Uganda, in September 2014 and replanted in
March 2015. In order to ensure disease exposure and establishment, the highly susceptible cultivar, TME204, was used in infector rows (Abaca et al., 2012). The infector plants were planted one month earlier at a spacing of 1 metre away from the test plants, so as to develop sufficient inoculum.

Namulonge is a known hotspot for viral cassava diseases (Kawesi et al., 2014); hence buildup of inoculum and its spread was assured. The field was also deliberately left open to white fly infestation and there was no spraying throughout the study. Initial foliar data were taken one month after planting (MAP). Visible foliar CBSD symptoms were assessed at approximately 3 months after planting. Subsequent data were taken monthly from the same plants for the next four months.

During field trials, plants were assessed for viral infection based on visible leaf and stem symptoms (Plate 1). At any one time, the presence of CBSD symptoms on lower leaves and middle leaves were the basis for sampling of infected plants and related observations. The initial symptoms were characterised by formation of chlorotic patterns alongside the leaf veins; while in some varieties, browning
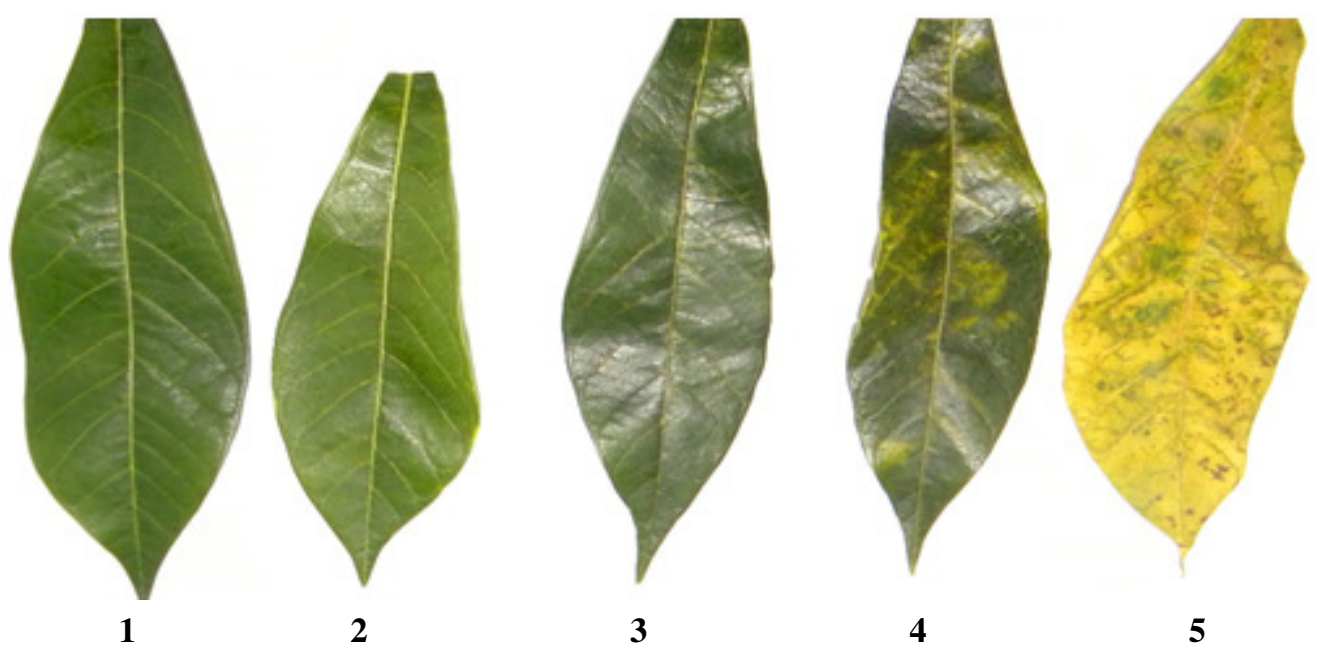

Plate 1. Progression of CBSD in cassava leaves with scores $1=$ leaf from clean plant, no CBSD, $2=$ Mild CBSD leaf veinal symptoms, 3 = beginning of vein necrosis and mottling, $4=$ Mottled leaf surfaces with over $50 \%$ of the leaf surface affected and $5=$ advanced CBSD infection with almost a $100 \%$ of the leaf surface mottled or browning. The numbers also represent the CBSD scores based on leaf symptamology only. 
lesions were observed on the leaf lamina. This was augmented with observed stem lesions on these plants.

Dry matter content. Cassava leaf dry matter content (DM) was determined immedaitely after collection of leaves to avoid moisture losses according to Benesi (2005) method for determination of dry matter in cassava but with modifications. Leaves were randomly selected from 30 plants and combined to make up to a sample of $10 \mathrm{~g}$ per plant. This weight was taken as fresh weight (W1), and the sample was dried using a dessicator at $105{ }^{\circ} \mathrm{C}$, until constant weight. The sample was weighed immediately after cooling to about $40^{\circ} \mathrm{C}$ (W2). The dry matter content was expressed as a percentage of fresh leaf weight as follows:

$$
\mathrm{DM}(\%)={ }^{\mathrm{W}} 2 /{ }_{\mathrm{W} 1} * 100
$$

\section{Determination of photosynthetic pigments.} Chlorophyll $a$, chlorophyll $b$ and carotenoids in cassava leaves were determined after extraction using cold acetone $\left(4^{\circ} \mathrm{C}\right)$ according to $\mathrm{Hu}$ et al. (2013) and the quantity determined according to the modifications (Nuwamanya et al., 2014). Five grammes of fresh leaves were weighed into a $50 \mathrm{ml}$ falcon tube and 40 $\mathrm{ml}$ of pure cold acetone (AR) were added and left to extract in a refrigerator at $4{ }^{\circ} \mathrm{C}$ for 24 hours. The extract was mixed uniformly and $0.5 \mathrm{ml}$ was diluted to $5 \mathrm{ml}$ with distilled water. The absorbances of these extracts were read using a spectrophotometer (BioChrome WPA biowave II) at $662 \mathrm{~nm}$ to quantify chlorophyll $a(C h l a), 644 \mathrm{~nm}$ for chlorophyll $b(C h l b)$ and $441 \mathrm{~nm}$ for carotenoids. The absorbance readings were also used to calculate the Chla:Chlb and Chla:carotenoids ratios.

Reducing sugars and starch content. Leaf samples were Lyophilised in a freeze dryer (Labconco Freezone18). The freeze dried leaf materials $\left(5 \mathrm{~g}\right.$ ) were homogenised in $1 \mathrm{M} \mathrm{HClO}_{4}$ $(25 \mathrm{ml})$, and the extract was centrifuged at $12,000 \mathrm{~g}$ for $5 \mathrm{~min}$ at $4{ }^{\circ} \mathrm{C}$ (Galtier et al., 1995).
The resultant supernatant was used to determine soluble sugars as total glucose, fructose and sucrose in a reaction mixture containing concentrated sulfuric acid and 5\% phenol (Dubois et al., 1956). The remaining centrifugation pellet was prepared for starch determination, by suspending it into water and incubating at $100{ }^{\circ} \mathrm{C}$ for $2 \mathrm{hr}$. Starch content was assayed enzymatically using a Megazyme Kit (Megazyme international, Australia).

Protein content. Total protein was extracted by grinding freeze dried leaves $(5 \mathrm{~g})$ from the freeze dryer (Labconco Freezone 18) in plant lysis buffer (Phosphate buffered saline). Insoluble debris was removed by centrifugation at $10,000 \mathrm{~g}$ for $10 \mathrm{~min}$. Protein concentration was estimated using the Bradford protein assay, with slight modifications to suit cassava, by using $10 \mathrm{ml}$ of the extract (Bradford, 1976).

Leaf dechlorophyllation and leaf structure changes. Freshly picked cassava leaves, representing the different disease progression stages (Plate 1), were dipped in boiling water for 30 seconds. The leaves were then placed on tissue paper (Whatman ${ }^{\circledR}$ Sigma Aldrich) to absorb the excess water, after which they were rolled and placed in pure acetone $(50 \mathrm{ml})$ kept at $4{ }^{\circ} \mathrm{C}$ in a falcon tube. The leaves were left in the dark for pigment extraction for four hours, after which they were removed and again placed on tissue paper to remove excess acetone. The dechlorophyllated leaves were photographed using a laboratory imaging camera. (Nikon instruments Inc) to show the differences in pigment distribution within the leaf.

Statistical analysis. In each plot, sampled leaves (top, middle and bottom) were averaged to represent particular plants at a particular sampling time. The variations between the means for the different harvest times and the differences between the test varieties were evaluated using a one way ANOVA. All the 
specific analyses were carried out using GENSTAT discovery Edition 2013 analysis software.

\section{RESULTS AND DISCUSSION}

Leaf dry matter contents. Leaf dry matter content did not change significantly $(\mathrm{P}>0.05)$ with disease progression (Table 1). No significant variety differences were observed for dry matter, although a higher value was observed for NASE 14 throughout the disease period. Over time, differences were noted in the tolerant variety NASE 14 , where a gradual increase in leaf DM with disease progression $(6 \%)$ was observed. In the susceptible and local varieties (TME 204 and Alado), the DM slightly declined initially and sharply dropped towards the end of the 6 month test period, as the disease was completely established. Establishment of the virus leads to loss in biomass (Shaltin and Wolf, 2000), and cell to cell viral movements may distort the leaf structure, leading to altered accumulation of biomass and subsequent losses for dry matter accumulation (Chen et al., 2000). This alteration of the plants' normal leaf structure may affect the photosynthetic pathway and energy assimilation, and hence what the plant finally deposits in to the roots for storage. Overall changes in leaf primary metabolite content are shown in Table 1.

Leaf pigment composition. Cassava leaf based pigments reduced as the disease progressed at a rate of $-0.096 \mathrm{ug}^{-1} \mathrm{~g} \mathrm{month}^{-1}$ for Chla and 0.032 ug month $^{-1}$ for Chlb (Table $1)$. Significant $(\mathrm{P}<0.05)$ variety specific differences were also observed in reduction of Chla; whereby a reduction in NASE 14 was $-0.120 \mathrm{ug}^{-1} \mathrm{~g} \mathrm{month}^{-1}$ compared to TME 204 $0.090 \mathrm{ug}^{-1} \mathrm{~g} \mathrm{month}^{-1}$ and Alado at $-0.080 \mathrm{ug}^{-1} \mathrm{~g}$ month $^{-1}$. For chlb, the rate of reduction was low for Alado (-0.026 ug $\left.{ }^{-1} \mathrm{~g} \mathrm{month}^{-1}\right)$ compared to TME $204\left(-0.032 \mathrm{ug}^{-1} \mathrm{~g} \mathrm{month}^{-1}\right)$ and NASE $14\left(0.036 \mathrm{ug}^{-1} \mathrm{~g} \mathrm{month}^{-1}\right)$. These rates of reduction in chlorophyll coincided with the changes in leaf metabolism, increasing the yellowing/browning area in the leaves (Plate 1).

In addition, an overall significant $(\mathrm{P}<0.05)$ reduction in the carotenoid pigments content, with disease progression was observed at a rate of $0.130 \mathrm{ug}^{-1} \mathrm{~g} \mathrm{month}^{-1}$, although a higher rate of reduction was observed for NASE 14 $\left(0.150 \mathrm{ug}^{-1} \mathrm{~g} \mathrm{month}^{-1}\right)$ and TME $204(0.121$ $\mathrm{ug}^{-1} \mathrm{~g}$ month $\left.^{-1}\right)$ compared to Alado $\left(0.059 \mathrm{ug}^{-1}\right.$ $\mathrm{g}$ month $\left.^{-1}\right)$. The high rate of reduction in pigment concentration for NASE 14, a supposedly tolerant variety, compared to susceptible varieties TME 204 and Alado may point to a reaction to infection by CBSD in which defense mechanisms are prioritised. However, the susceptible varieties seem poised to maintain energy consuming photosynthetic metabolism in form of production of new pigments and related processes.

Primary carbohydrate metabolites composition. There was a general and significant $(\mathrm{P}<0.05)$ reduction in primary carbohydrate composition (total reducing sugar and starch contents) in the leaf for all the tested varieties (Table 1). Unlike the pigments, the rate of reduction in reducing sugars was higher for the susceptible variety, TME $204\left(0.28 \mathrm{ug}^{-1} \mathrm{~g} \mathrm{month}^{-1}\right)$, compared to the tolerant variety NASE $14\left(0.22 \mathrm{ug}^{-1} \mathrm{~g}\right.$ month $\left.^{-1}\right)$ and Alado $\left(0.18 \mathrm{ug}^{-1} \mathrm{~g}\right.$ month $\left.^{-1}\right)$. Related to this, a reduction in starch content was not significantly $(\mathrm{P}>0.05)$ different among the tested varieties and ranged from 0.22-0.26 $\mathrm{ug}^{-1} \mathrm{~g} \mathrm{month}^{-1}$. The pattern involved an initial reduction immediately after disease onset for a period of three months, followed by a slight increment. However, the reduction in reducing sugar content observed could be solely due to the malfunction of the photosynthetic apparatus. This reduction, as observed above, is as a result of reduction in light capturing pigments (chlorophylls) resulting into production of lower amounts of the photosynthates (sugars).

The initial increase in protein content was followed by a reduction as symptom severity increased. A significant $(\mathrm{P}<.05)$ reduction in 
TABLE 1. Cassava varietal changes in leaf dry matter, pigment concentration, primary carbohydrates and protein for the five months observation period in a study at $\omega_{\infty}$ NaCRRI in Uganda

\begin{tabular}{|c|c|c|c|c|c|c|c|c|}
\hline $\begin{array}{l}\text { Sampling } \\
\text { time } \\
\text { (Monthly) }\end{array}$ & Variety & Leaf dry matter $(\%)$ & Chlorophyll a & Chlorophyll b & Carotenoids & Reducing sugars & Proteins (\%) & Starch \\
\hline \multirow[t]{3}{*}{1} & NASE 14 & $30.307 \pm 2.552$ & $0.560 \pm 0.073$ & $0.206 \pm 0.022$ & $0.968 \pm 0.076$ & $1.438 \pm 0.101$ & $0.576 \pm 0.077$ & $1.552 \pm 0.276$ \\
\hline & TME 204 & $31.466 \pm 1.155$ & $0.610 \pm 0.139$ & $0.238 \pm 0.047$ & $1.025 \pm 0.112$ & $1.821 \pm 0.399$ & $0.642 \pm 0.151$ & $1.508 \pm 0.378$ \\
\hline & Alado & $31.130 \pm 0.567$ & $0.509 \pm 0.185$ & $0.201 \pm 0.069$ & $0.960 \pm 0.296$ & $1.234 \pm 0.093$ & $0.500 \pm 0.041$ & $1.365 \pm 0.156$ \\
\hline \multirow[t]{3}{*}{2} & NASE 14 & $30.483 \pm 1.628$ & $0.345 \pm 0.056$ & $0.107 \pm 0.013$ & $0.584 \pm 0.085$ & $1.164 \pm 0.062$ & $0.604 \pm 0.052$ & $0.916 \pm 0.172$ \\
\hline & TME 204 & $31.689 \pm 2.807$ & $0.414 \pm 0.145$ & $0.134 \pm 0.036$ & $0.704 \pm 0.179$ & $1.103 \pm 0.105$ & $0.633 \pm 0.037$ & $1.179 \pm 0.131$ \\
\hline & Alado & $30.830 \pm 1.737$ & $0.351 \pm 0.153$ & $0.106 \pm 0.044$ & $0.565 \pm 0.207$ & $0.918 \pm 0.125$ & $0.592 \pm 0.081$ & $0.932 \pm 0.626$ \\
\hline \multirow[t]{3}{*}{3} & NASE 14 & $31.769 \pm 1.181$ & $0.289 \pm 0.106$ & $0.105 \pm 0.037$ & $0.551 \pm 0.136$ & $0.813 \pm 0.256$ & $0.349 \pm 0.093$ & $0.475 \pm 0.172$ \\
\hline & TME 204 & $30.787 \pm 0.385$ & $0.442 \pm 0.190$ & $0.180 \pm 0.075$ & $0.832 \pm 0.313$ & $0.705 \pm 0.139$ & $0.404 \pm 0.047$ & $0.408 \pm 0.112$ \\
\hline & Alado & $30.863 \pm 0.831$ & $0.375 \pm 0.145$ & $0.138 \pm 0.047$ & $0.680 \pm 0.151$ & $0.584 \pm 0.106$ & $0.333 \pm 0.076$ & $0.398 \pm 0.236$ \\
\hline \multirow[t]{3}{*}{4} & NASE 14 & $32.178 \pm 2.135$ & $0.102 \pm 0.054$ & $0.092 \pm 0.047$ & $0.502 \pm 0.237$ & $0.808 \pm 0.140$ & $0.391 \pm 0.071$ & $0.636 \pm 0.041$ \\
\hline & TME 204 & $31.909 \pm 0.504$ & $0.142 \pm 0.042$ & $0.137 \pm 0.040$ & $0.667 \pm 0.211$ & $0.925 \pm 0.217$ & $0.447 \pm 0.100$ & $0.697 \pm 0.014$ \\
\hline & Alado & $32.455 \pm 0.986$ & $0.182 \pm 0.130$ & $0.099 \pm 0.030$ & $0.466 \pm 0.131$ & $0.647 \pm 0.126$ & $0.354 \pm 0.120$ & $0.432 \pm 0.028$ \\
\hline \multirow[t]{3}{*}{5} & NASE 14 & $31.738 \pm 5.763$ & $0.104 \pm 0.036$ & $0.039 \pm 0.013$ & $0.261 \pm 0.041$ & $0.556 \pm 0.109$ & $0.357 \pm 0.125$ & $0.462 \pm 0.170$ \\
\hline & TME 204 & $30.975 \pm 4.056$ & $0.201 \pm 0.074$ & $0.074 \pm 0.023$ & $0.455 \pm 0.076$ & $0.560 \pm 0.028$ & $0.435 \pm 0.087$ & $0.658 \pm 0.078$ \\
\hline & Alado & $29.477 \pm 5.260$ & $0.200 \pm 0.090$ & $0.073 \pm 0.030$ & $0.397 \pm 0.127$ & $0.442 \pm 0.096$ & $0.366 \pm 0.094$ & $0.305 \pm 0.027$ \\
\hline $\operatorname{LSD}(0.05)$ & & 4.455 & 0.375 & 0.137 & 0.540 & 0.276 & 0.149 & 0.389 \\
\hline $\mathrm{Cv}(\%)$ & & 8 & 47 & 44 & 35 & 18 & 19 & 29 \\
\hline
\end{tabular}


total protein content was observed for all varieties much as the drop was higher for NASE 14 and TME $204 \quad\left(0.060 \mathrm{ug}^{-1} \mathrm{~g}\right.$ month $^{-1}$ ) compared to Alado (Table 1). The initial increment in protein content on viral infection may signify increments in various defense protein components such as antioxidant enzymes, representing elements of the sensitivity response in which a plant protects its cell components. Successful establishment of the virus overrides these responses, resulting into subsequent loss of existing protein through protein degradation and the shutdown of protein producing processes (Chen et al., 2000).

Leaf pigment contents. The levels of photopigments were significantly $(\mathrm{P}>0.05)$ different between the healthy and diseased treatments, as time progressed (Table 1 and Fig. 1). However, there were no significant $(\mathrm{P}>0.05)$ differences for the photo-pigments across the varieties. The decline in levels of these photopigments was expected, since chlorosis and yellowing were observed in the diseased plants compared to the healthy ones (Plate 1). However, the rates of fall were overwhelming compared to normal mature plants. In fact, more than $80 \%$ decline in chlorophyll a was observed; while an average $70 \%$ decline was observed for both chlorophyll $b$ and carotenoids, as the disease progressed (Fig. 1). The losses could be essentially attributed to distortion of the leaf structure; hence compromising the functioning of pigment synthesis pathways that essentialy involve light capture by the leaf (Palanisamy et al., 2009). What follows is a photo-inhibitory process that obviously affects the amount of light that the plant can intercept and utilise in photosynthesis. This affects the amount of photoassimilates in the leaves as the source.

Losses in these photo-pigments also result into decline in leaf integrity, affecting leaf morphology and structure. The decline observed in carotenoid contents robs the plants of its protective mechanisms against damaging radiation, and may be due to leaf chlorosis, leaf blister formation, size reduction and deformation (Palanisamy et al., 2009; Srivastava et al., 2010). Such morphological, changes further exacerbate CBSD effects on cassava leaf physiology and may lead to photodamage of the chlorophylls systems (Vass, 2011).

The observed changes in leaf integrity might be the underlying factor in loss of chlorophyll contents in the leaf, and hence reduction in leaf life, leading to rapid senescence. Analysis of these pigments showed that the top-most leaves had higher levels compared to the yellow and brown chlorotic leaves at the bottom of the plant. This may explain the observations made by Hillocks et al. (1996), that the virus affects mostly mature or nearly mature leaves. Therefore, the losses in leaf pigmentation that occur, alongside viral infection, affect mature leaf physiology and hamper leaf based growth and developmental responses.

It also points to the fact that the observed browning of older leaves is not only due to loss of chlorophyll in the leaves, but also to viral effects on leaves such as altered lignin metabolism (Nuwamanya et al., 2015). Thus, what are expected to be fully functional photosynthetic leaves with more pigmentation may behave like bottom old leaves, further exacerbating the effects of the virus on the photosynthetic potential of the plant.

Initially, an increment in the Chla:Chlb ratio was observed (Fig. 2), which later fell as the disease progressed, indicating more losses in Chla than Chlb. Given the relevance of chlorophyll a in a C3-C4 intermediate plant like cassava (El-Sharkawy and Cock, 1990), the effects of cassava brown streak virus are largely disastrous on plant yield components. As the diseases progressed, this ratio fell further, showing a sustained and incremental effect of the cassava brown streak virus (CBSV) on Chla. In essence, there is an attempted reversion of the role of chlorophyll a as a better photosynthetic conformation of chlorophyll to chlorophyll b, which obviously 


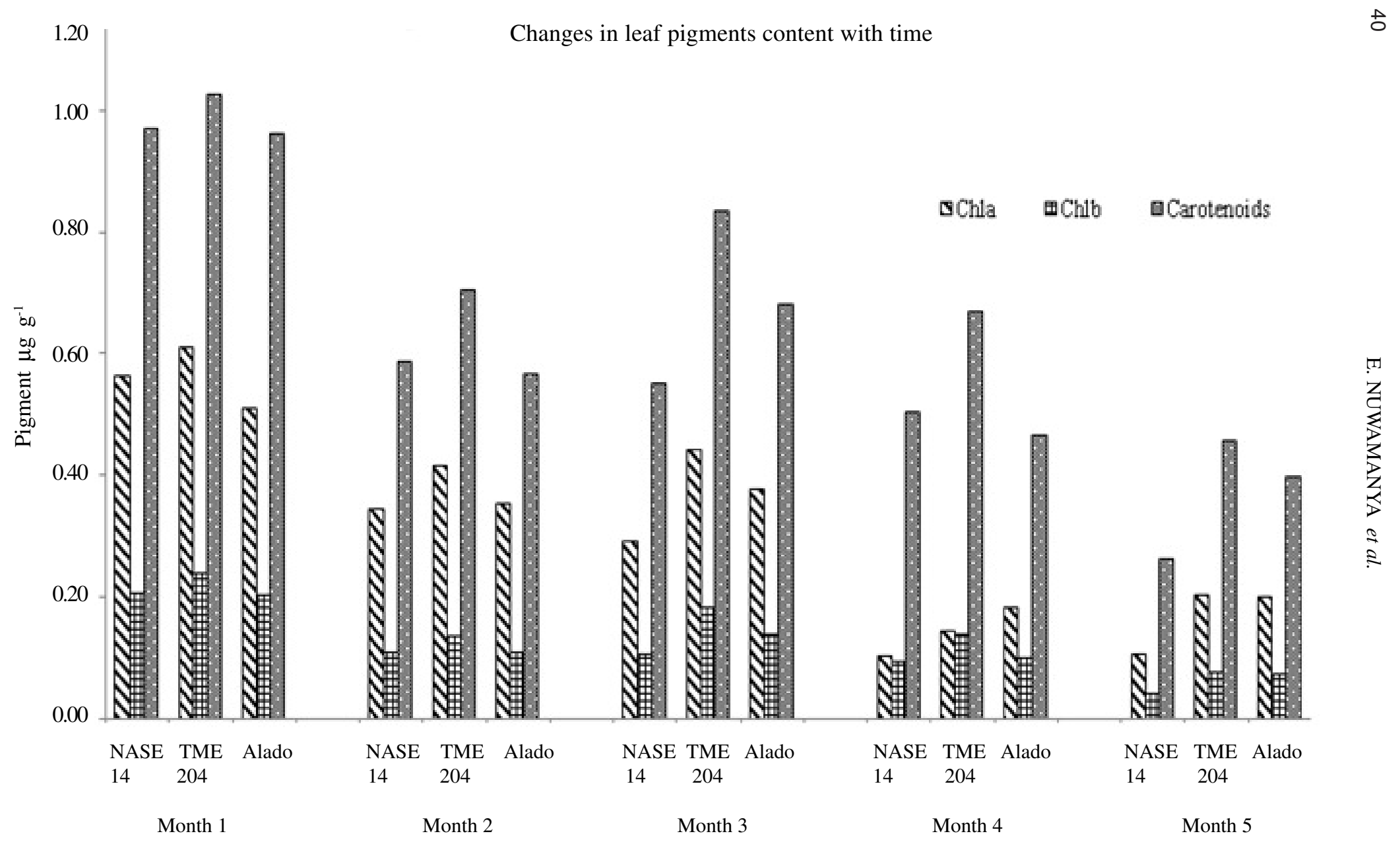

Figure 1. Representation of the changes in photosynthetic pigments (chlorophyll a-Chla, chlorophyll b-Chlb and carotenoids) as the disease (CBSD) progresses with time (Months) in cassava leaves. 


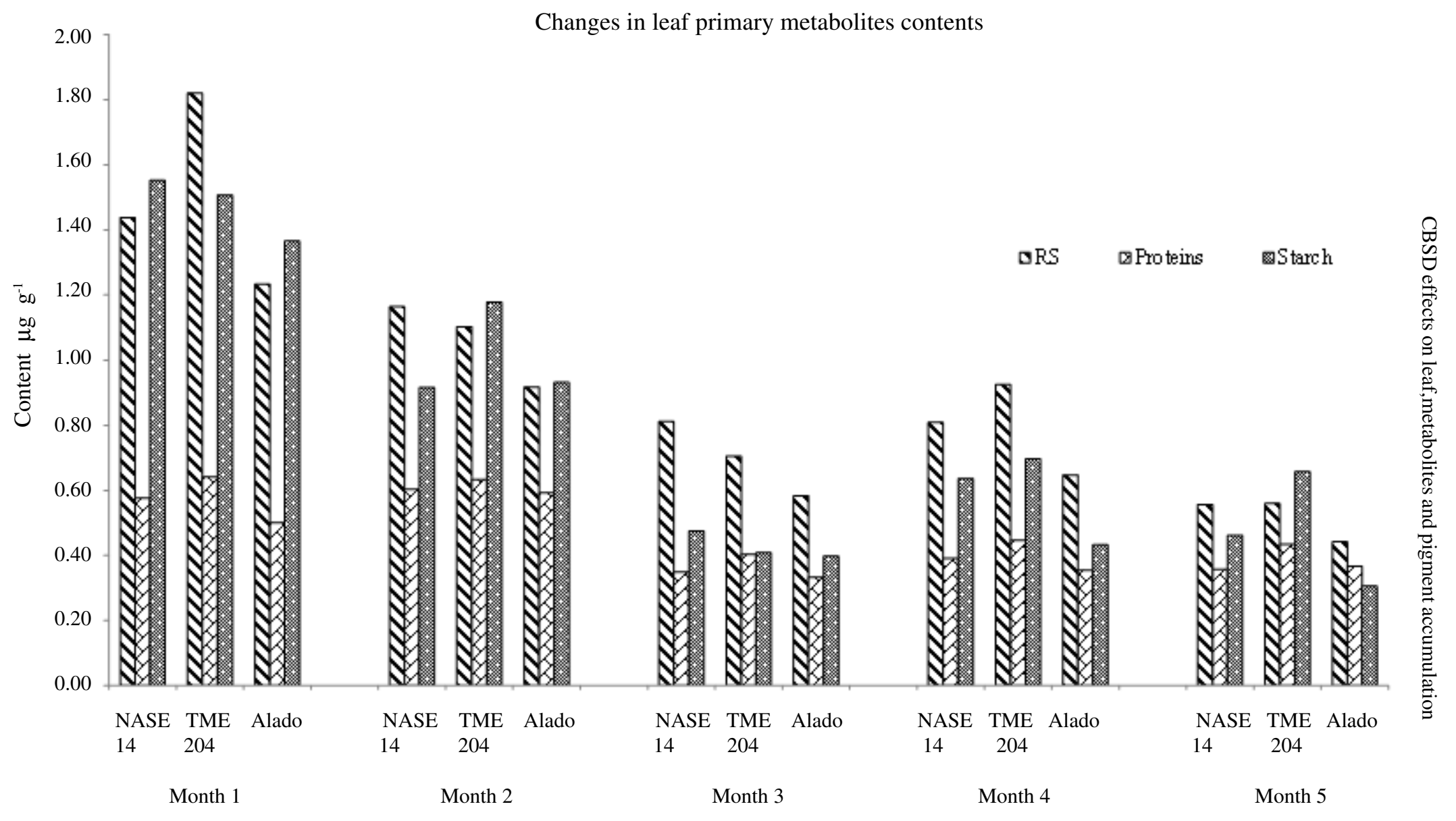

Figure 2. Representation of the changes in primary metabolites (Reducing Sugars-RS, Proteins, Starch) as the disease (CBSD) progresses with time (Months) in cassava leaves. 
affects the performance of the photo-system, hence negatively affecting the yield components.

According to Srivastava et al. (2010) plant viruses inhibit the production of chlorophyll and other plant based pigments. Specifically, viruses that cause yellowing or discolouration of leaves lead to destruction of the chlorophyll pigments, in addition to loss in leaf nutrient content (Raj et al., 2005). Thus, as observed in this study, the most likely explanation would be viral destruction of photosynthetic apparatus in the fully developed leaves. However, the possibility of inhibition of chloroplast development and/or the disruption of existing chloroplast during chlorosis is possible as shown in Plate 2. Detailed observation of dechlophyllated leaves, revealed distortions in the leaf morphology and structure (Plate 2), with green patches suggesting the possibility of distorted chloroplasts.

Total leaf protein and carbohydrates contents. Figure 2 shows the progressive changes in levels of proteins, reducing sugars, and starch at different sampling times (H1H5). The levels of reducing sugars were significantly low in the less tolerant variety TME 204, as the disease state progressed, compared to the tolerant variety NASE 14 . Reducing sugars play an important role in the plants' immune response as signaling molecules (Rolland et al., 2006) and may change during diseased states due to either decreased synthesis of glucose related metabolites or increased respiration, hence over utilisation of glucose (Shaltin and Wolf, 2000). Therefore, the observed reduction of reducing sugars with time, points to an interaction between reduced sugar synthesis and increased respiration; but with increased respiration since the starch content was equally reducing (Fig. 2).

Higher levels of reducing sugars in the tolerant variety may influence the coping mechanisms in such a variety since reducing carbohydrate components are key in alternate sugar metabolism meant for production of

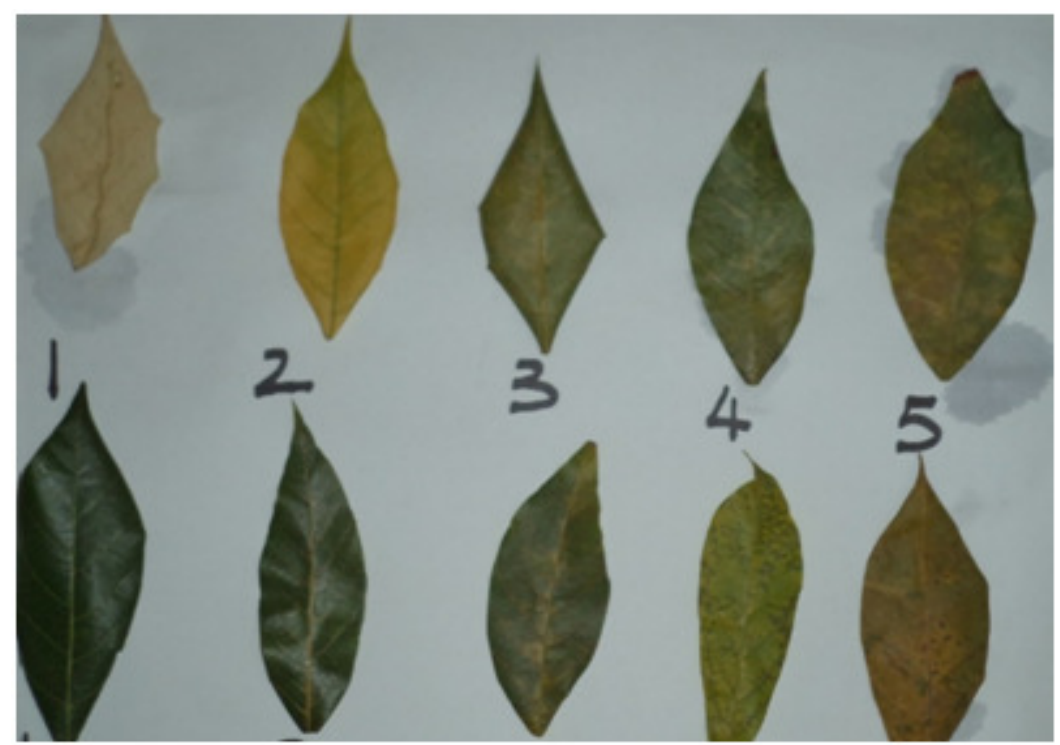

Plate 2. Representation of changes in leaf structure due to disease progression. Please note that dechlorophyllated leaves (top row) after treatment with hot ethanol and fresh leaves of different leaf CBSD scores (bottom row).The numbers 1, 2, 3, 4, and 5 represent the CBSD leaf scores. 
defense components. These reducing sugars also play an important role as carbon and energy sources for the plant.

These reducing sugars also play an important role as carbon and energy sources for the plant (Shina and Shravastava, 2010) and affect primary metabolite levels for the plant including starch deposition in the storage roots (Nuwamanya et al., 2015). In addition, low production of reducing sugars may be due to low carbon dioxide exchange, as observed in sugar cane (Goncalcaves et al., 2005) or a decline in chlorophyll levels (El-Sharkawy and Cock,1990). This obviously results into reduced photosynthetic ability in diseased plants, leading to low sugar production, hence affecting downstream sugar mediated responses such as plant immunity. Thus, the susceptible varieties may end up lacking appropriate response mechanisms to viral infection as the sugar levels decrease increasing their susceptibility and failure to revert back to normal metabolism.

Generally, the protein levels were significantly $(\mathrm{P}<0.05)$ higher in diseased plots than healthy ones (Fig. 2); and they reduced with time in all varieties, although the less tolerant varieties had higher reduction rates. The observation can be attributed to altered protein metabolism due to viral infection in addition to possible reduced nitrogen use efficiency in the diseased state (Olea et al., 2004). As such, an increase in content of nitrogenous compounds for diseased leaves may be attributed to a shift in metabolism towards production of defensive proteins. The cassava plant tends to manufacture more nitrogenous compounds such as cyanide for defense purposes, which increase the plant's relative nitrogen contents and total proteins (Mohamed, 2011). They accumulate in the virus-infected cells at the onset of innate immune response. This increases protein levels in the diseased leaves of the very plant, which may not necessarily be the case in the healthy ones.
There was also a noticeable decline in starch content in the leaves with disease progress (Fig. 2). The diseased leaves had a significantly lower starch content than the healthy ones $(\mathrm{P}<0.05)$. This can be attributed to the low levels of reducing sugars, as observed above. The precursors for starch synthesis (i.e, the reducing sugars) are low, which would obviously affect the starch content. Similarly, the reducing sugars may be channeled into the innate immunity response, at the expense of what would be available for starch synthesis. It is expected that starch is deposited in the roots for storage as the plant grows, since the cassava storage metabolites are mainly in the form of starch. However, a study on root components by Nuwamanya et al. (2015) observed low starch yields from diseased plants. Therefore, the starch synthesis mechanism for the plant is hindered by viral infection.

Effect of CBSD on leaf structure. The effects of cassava brown streak disease (CBSD) on leaf structure were studied by understanding the extent to which the plants developed normal leaf structures (Plate 2). Normal and uninfected leaves (Labelled 1) were completely decolourised on treatment with 98\% ethanol; while as the disease score progressed; most of the leaves could not be decolourised. As presented in Plate 2, the leaves maintained a significant amount of brown to green colourations, which could be due to damage to chloroplasts. In fact, at score five (Labelled 5) the dechlorophyllated leaf had more green patches, with significant brown colourations, and was not different from untreated leaf. On further analysis, it was realised that the green patches observed in untreated leaves for score 3 and 5 were distinctively present even after the decchlorophyllation procedure. The distortions observed as greenish islands on the leaf are well spread along the vein and even on leaf lamina. The result shows that the virus does 
not only reduce the chlorophyll content, but also affects leaf morphology, pigment distribution and pigment functioning. Such distortions which may result from deposition of secondary metabolic products in the chloroplasts may be a reflection of the distortion of the primary synthetic processes resulting into production of other products in the leaf apart from normal chlorophyll based pigments.

From the above observation, we note that cassava brown streak viruses have significant effects on both leaf metabolism and structure. The effects on leaf metabolism are mainly due to viral effects on photosynthetic metabolism that reduce the production of vital components of leaf growth and development such as reducing sugars. Such a response affects down stream processes that are dependent on sugar metabolism, including the production of other key elements such as proteins and pigments. These events severely compromise cassava plant functioning, and thus yield. It should be noted also that compromise in cassava leaf primary metabolism may result into altered secondary metabolic responses, which in turn affect leaf morphology as have been observed. Such alterations in leaf morphology further impede the leaf from performing its primary functions. Therefore, in the design of CBSD prevention and management strategies, the central focus should be put on reducing or halting the effects of the virus on leaf metabolism as the source organ of the cassava plant.

\section{ACKNOWLEDGEMENT}

We thank the cassava team, especially the technicians (Mr. Oba John, Mr. Jacob Omara and Ms. Genevieve Einau) of National Crops Resources Research Institute (NaCRRI) for helping and advising in execution of this work.

\section{REFERENCES}

Abaca, A., Kawuki. R., Tukamuhabwa, P., Baguma, Y., Pariyo A., Alicai, T., Omongo,
C.A. and Bua, A. 2012. Evaluation of local and elite cassava genotypes for resistance to cassava brown streak disease in Uganda. Journal of Agronomy 11: 65-72.

Alicai, T., Omongo, C.A., Maruthi, M.N., Hillocks, R.J., Baguma, Y., Kawuki, R., Bua, A., Otim-Nape, G.W. and Colvin, J. 2007. Re-emergence of cassava brown streak disease in Uganda. Plant Disease 91:24-29.

Bradford, M.M. 1976. A rapid and sensitive method for the quantitation of microgram quantities of protein utilizing the principle of protein-dye binding. Anall. Biochemistry 72:248-254.

Chen, M.H., Sheng, J.,, Hind, G., Handa, A. and Citovsky, V. 2000. Interaction between the tobacco mosaic virus movement protein and host cell pectin methylesterases is required for viral cell-to-cell movement. EMBO Journal 19: 913-920

Dubois, M., Gilles, K., Hamilton, K., Rebers, A. and Smith, F.1956. Colorimetric method for determination of sugars and related substances. Analytical Chemistry 28:350356.

El-Sharkawy, M. and Cock, J.H. 1990. Photosynthesis of cassava (Manihot esculenta). Experimental Agriculture 26: 325-340

Galtier, N., Foyer, C.H., Murchie, E. , Lascève, G. and Betsche, T. 1995. Effects of light and atmospheric carbon dioxide enrichment on photosynthesis and carbon partitioning in the leaves of tomato (Lycopersicon esculentum L.) plants overexpressing sucrose phosphate synthase. Journal of Experimental Biology 46:1335-1344.

Hillocks, R.J., Raya, M. and Thresh, J.M. 1996. The association between root necrosis and above-ground symptoms of brown streak virus infection of cassava in southern Tanzania. International Journal of Pest Management 42(4):285-289.

Mbanzibwa, D.R., Tian, Y.P., Tugume, A.K., Mukasa, S.B., Tairo, F., Kyamanywa, S., Kullaya, A. and Valkonen, J.P. 2009. Genetically distinct strains of cassava 
brown streak virus in the Lake Victoria basin and the Indian Ocean coastal area of East Africa. Archives of Virology 6:353359.

Mbanzibwa, D.R., Tian, Y.P., Tugume, A.K., Mukasa, S.B., Tairo, F., Kyamanywa, S., Kullaya, A. and Valkonen, J.P. 2011. Simultaneous virus-specific detection of the two cassava brown streak-associated viruses by RT-PCR reveals wide distribution in East Africa, mixed infections, and infections in Manihot glaziovii. Journal of Virology Methods 171:394-400.

Mohamed, E.F. 2011. Changes in protein, amino acids composition and leaf cells of beet plants (Beta vulgaris L.) due to Beet mosaic virus (BtMV) infection. Journal of American Science 7(12):845-854.

Moreno, I.M., Malpica, J.M., Diìaz-Pendoìn J. A., Moriones, E., Fraile, A. and GarciaArenal, F. 2004. Variability and genetic structure of the population of watermelon mosaic virus infecting melon in Spain. Virology 318:451-460.

Nuwamanya, E., Baguma, Y., Atwijukire, E., Acheng, S. and Alicai, T. 2015. Effect of cassava brown streak disease (CBSD) on cassava (Manihot esculenta Crantz) root storage components, starch quantities and starch quality properties. International Journal of Plant Physiology and Biochemistry 7(2):12-22.

Nuwamanya, E., Rubaihayo, P.R., Mukasa, S.B., Kyamanywa, S., Hawumba, J. and Baguma, Y. 2014. Influence of spectral properties on cassava leaf development and metabolism. African Journal of Biotechnology 13(7):834-843.

Ogwok, E., Odipio, J., Halsey, M., GaitanSolis, E., Bua, A., Taylor, N.J., Fauquet, C.M. and Alicai, T. 2012. Transgenic RNA interference (RNAi)-derived field resistance to cassava brown streak disease. Molecular Plant Pathology 13:1019-1031.

Olea, F., Pérez-Garcia A. and Canton, F.R.. 2004. Up-regulation and localization of asparagine synthetase in tomato leaves infected by the bacterial pathogen Pseudomonas syringae. Plant Cell and Physiology 45:770-780.

Palanisamy, P., Michael, P.I. and Krishnaswamy, M. 2009. Physiological response of yellow vein mosaic virus infected bhendi (Abelmoschus esculentus) leaves. Physiological and Molecular Plant Pathology 74:129-133.

Pennisi, E. 2010. Armed and dangerous. Science 327:804-805.

Rolland, F., Baena-Gonzalez, E. and Sheen, J. 2006. Sugar sensing and signalling in plants: Conserved and novel mechanisms. Annual Review of Plant Biology 57:675709.

Raj, S.K., Khan, M.S., Singh, R., Kumari, N. and Praksh, D. 2005. Occurrence of yellow mosaic geminiviral disease on bitter gourd (Momordica charantia) and its impact on phytochemical contents. International Journal of Food Science and Nutrition 56:185-192.

Shalitin, D. and Wolf, S. 2000. Cucumber mosaic virus infection affects sugar transport in melon plants. Plant Physiology 123(2):597-604.

Srivastava, M., Gupta, U.P. and Sinha, A. 2010. Viral diseases of leguminous crops. Journal of Scientific Resources 54: 135152.

Vass, I. 2011. Role of charge recombination processes in photodamage and photoprotection of the photosystem II complex. Physiology of Plants 142(1):6-16. 